\title{
Self-Esteem and Motivation for Learning among Minority Students: A Comparison between Students of Pre-Academic and Regular Programs
}

\author{
Khawla Zoabi \\ The College of Sakhnin of Teacher Education, Sakhnin, Israel \\ Email: Khawla_zoabi2011@hotmail.com \\ Received October $6^{\text {th }}$, 2012; revised November $8^{\text {th }}$, 2012; accepted November $22^{\text {nd }}, 2012$
}

\begin{abstract}
Motivation for learning, which explains the impulses and motives for an individual to act to achieve his or her goals, is of great importance for students, particularly students of pre-academic preparatory programs. The literature suggests a relationship between self-esteem and motivation, yet there is a lack of studies that consider self-esteem among students in pre-academic preparatory programs and its relationship to motivation for learning. The main question of this study is whether there are differences in the motivation for learning among students in preparatory programs and regular students. Thus, it examines the relationship between self-esteem and motivation for learning among pre-academic preparatory program students and among regular students in their first year of study. Data collection was based on a questionnaire. The sample included 175 students who were enrolled in courses at Sakhnin College. Of these students, 43\% were in the pre-academic program and $57 \%$ were in their first year of study in other departments. The findings show a positive relationship between self-image and motivation for learning among the two populations. The findings have theoretical implications as well as practical implications. They indicate that pre-academic students are not "lost"; they have motivations similar to the regular students. The practical pedagogical implications suggest that pre-academic students should be exposed to academic subjects beyond the core subjects and should be treated as equal to other students at various levels of the academic system.
\end{abstract}

Keywords: Motivation for Learning; Self-Esteem; Arab Minority in Israel; Pre-Academic Program

\section{Introduction}

Pre-academic preparatory programs offer a helpful framework; they provide a "second chance" for students to obtain a high school diploma, and they provide opportunities for further academic studies for students who initially failed to achieve. These opportunities affect the expectations of students and their families. Therefore, students who study in this framework must be highly motivated to learn to overcome their lack of achievement and low expectations. This paper focuses on the relationship between self-esteem and motivation for learning among pre-academic preparatory program students. To understand the position of these students in terms of academic integration, this study compared students in a pre-academic preparatory program with regular academic first-year students in various departments. The rationale for comparing regular first-year students and pre-academic students is that first-year students are academically similar to pre-academic preparatory program students, which facilitates a comparison of the education of preacademic students. It is important to explore this issue to identify differences between these two groups that may be helpful in promoting success among pre-academic students.

There are 46 pre-academic programs for the Jewish population in Israel. These programs enroll 11,383 students, of which only 5.5\% are Arabs (CBS, 2008). Unfortunately, there was no specific pre-academic preparatory program among the Arab population until 2010, when an Arab college, Sakhnin College, established a new pre-academic program.
The Arab minority in Israel was approximately 1.6 million people in 2012, about $20 \%$ of the entire population (see Jabareen, 2006, 2008, 2009; Zoabi \& Awad, 2012; Zoabi \& Savaya, 2012). No program is adequate for young Arab, who constitute $20 \%$ of the general population of the state, and only a few students consider these tracks a solution for them (Awad, 2012).

According to the Israeli Central Bureau of Statistics, 43.6\% of Arabs who attempted to enter the university in 2006 were rejected. This is more than twice the percentage of Jews rejected, which was $20.5 \%$. Failure to provide equal opportunities for Arabs, the lack of programs for the pre-academic Arab population, and the required level of achievement for acceptance to universities prevent Arab high school students from adequately integrating into academic studies in Israel (Awad, 2009).

Moreover, pre-academic preparatory programs have the ability to bridge the gaps between different ethnic groups and among high school students of the same ethnic group. These programs also have the power to strengthen capabilities and improve the conditions for students to enter higher education and use their potential. The greatest advantage of preparatory programs is that they are framed as "corrective” programs that provide students with the tools to allow them to pursue higher education. A preparatory pre-academic educational program offers a second chance for students who could not succeed during their first opportunity and prepares these students for the requirements to eventually obtain an academic degree. In addition to the goal of reducing educational gaps, these programs have social goals of 
reducing social gaps and integrating students of low socio-economic status into higher education. The findings of previous studies have shown that the most important role of social and preparatory programs is to increase the number of students who can take advantage of the help offered by these academies to obtain a college degree (Arieli, 1997).

Previous studies have shown that most applicants for the preacademic programs belong to low-middle class households, and their parents have low achievement in education (Hyosh, 2000). Preparatory studies blur the differences arising from social inequality in society. However, despite these preparatory studies, personal and scholastic differences remain (Awad, 2009).

In sum, pre-academic preparatory programs provide a second chance for disadvantaged and low-income groups. Preparatory programs provide students with a way to attain their social mobility goals and to integrate equally into higher education (Hyosh, 2000).

To promote and increase the number of Arab students in the academy, Sakhnin College established its Preparatory Academy Program in 2010. Sakhnin College is an academic institution that is supervised and financed by the Ministry of Education and is accredited by the Council for Higher Education to award the Bachelor's in Education (B.Ed.) and teaching certificates in early childhood, special education, English, mathematics and computer science. The main purpose of the Preparatory Academy Program in Sakhnin is to increase access to higher education for high school graduates from the Arab minority population and to provide a second chance for students who wish to acquire academic education and who, for various reasons, did not complete their high school education.

The Preparatory Academy Program of Sakhnin has achieved great success in terms of the growth of its student enrollment, from 80 students at the beginning of 2010 to 200 enrolled students in 2012. Based on this success, the main topic of interest in this paper is the motivation for learning and self-esteem among these students.

This paper examines the relationship between self-esteem and motivation for learning among Arab students studying at the Preparatory Academy Program in Sakhnin College. The study involved two groups. The first group includes pre-academic students studying for a diploma to replace their matriculation scores. These students completed 12 years of schooling but, for various reasons, do not have a full matriculation certificate or have very low matriculation scores. They want to complete their high school diploma or upgrade their achievements to an appropriate level for academic institutions.

Despite the importance of this topic, the literature review shows that very few studies have examined this relationship between self-esteem and motivation for learning, particularly among Arab students. Thus, this paper aims to fill this gap and to contribute to the accumulated knowledge in this field by assuming that an individual's self-esteem is related to his or her motivation for learning, as explained below. Specifically, this paper aims to examine the relationship between self-esteem and motivation for learning among pre-academic preparatory students and regular students.

\section{Motivation for Learning}

Motivation is a theoretical concept that refers to an individual's impulses and motives for action. Motivation describes how a person responds to a need or a general desire and initi- ates various actions to achieve his/her goals (Elliot \& Thrash, 2001). Motivation is the underlying cause of behavior (Guay et al., 2010), the factor that moves a person to do or not do something (Broussard \& Garrison, 2004). Learning motivation is culturally and socially constructed, and it has different meanings in different cultures and societies (Salili \& Hoosain, 2007). In recent decades, studies have emphasized the importance of motivation for learning in students' adaptation to studying and ability to manage difficulties and failure (Endler, Rey, \& Butz, 2001). In the educational context, motivation is the most important factor in helping educators improve learning (Williams \& Williams, 2011) and in explaining the levels at which a student shows interest and ability in various occupations (Brophy, 2004).

Scholars' perceptions of educational goals vary, and these perceptions affect the definition of motivation for learning among students (Valle et al., 2003). For example, the psychological achievement approach sees the urge for action as the unconscious motivation of an individual in his/her first years of life and that is influenced by family, society and culture (Elliot, 2006; Furtner \& Rauthmann, 2011; McClelland, 1961, 1965; McClelland, Koestner, \& Weinberger, 1989; Robbins et al., 2004).

Self-determination theory (SDT) emphasizes the universal tendency to develop one's inherent internal potential and to realize one’s self (Deci, 2008; Deci \& Ryan, 2012, 2008). Similar to the approach of psychological achievement, self-determination theory emphasizes the effect of social conditions on increases or decreases in individual motivation. Theories of selfefficacy and goal achievement approaches suggest that higher motivation produces more achievements (Ames, 1992; Roberts \& Dyer, 2005; Schunk, 1991, 2000).

The literature identifies two types of motivation, external and internal (Nakanishi, 2002). Internal motivation lies within a person and involves the urge to be desirably and pleasantly engaged. External motivation is affected by external factors and pushes an individual to engage in activities as a means to achieve goals and ends (Klonis, Plant, \& Devine, 2005). The literature indicates that actions driven by external motivation are characterized by lower investment and efforts toward simple tasks, whereas activities driven by internal motivation are characterized by greater effort toward complex and challenging tasks (Ames, 1992; Ames \& Ames, 1990; Nakanishi, 2002).

The theory of self-direction suggests that self-direction is a naturally occurring process (Chee et al., 2011; Gibbons, 2002). Self-directed people show a wide range of curiosity, self-discipline, independence, persistence, goal orientation, responsibility, and enjoyment in learning (Nor \& Saeednia, 2009). Self-directed people are motivated to learn, to develop a sense of ownership over their learning and to identify their own learning objectives (Chee et al., 2011).

Motivation for learning is influenced by various factors (Packer, 2004). These factors include personal motives, such as the psychological need for achievement and success or individual self-esteem (Katz, 2004). Scholars believe that learning motivation and self-esteem vary by individual (Sowislo \& Orth, 2012), and there is a positive correlation between motivation for learning and self-esteem (Harlen \& Crick, 2003).

Saada (2007) believes that motivation for learning can be attributed to various factors, such as job readiness, interest in learning tasks, freedom of choice, level of involvement, and personality factors. The basic assumption is that a student is driven 
to learn through self-guidance and is able to provide feedback, which is based on three dimensions: 1) the perception of selfefficacy (Self-Efficacy), which involves one's beliefs about success, challenges, strategies, processing and organization; 2) expression of achievement orientation (Achievement Orientation), through which a student identifies the importance of task, includes the setting of goals, planning, supervision and self-guidance; and 3) intrinsic motivation (Intrinsic Motivation), which arises out of curiosity and the desire to understand the task itself.

Intrinsic motivation involves the creation of a learning atmosphere, effort, perseverance and self-reinforcement. A study conducted among students in an early childhood course found that the dominant motives for learning are self-fulfillment and achievement (Awad, Zoabi, \& Khalil, 2009).

\section{Self Esteem}

Self-esteem appears under various names, such as "selfconcept”, "self-image”, “self-presentation”, or "self-evaluation”. It reflects the totality of a person's subjective perceptions, attitudes, feelings, physical characteristics and behaviors with respect to himself/herself (Levine \& Smolak, 2002; Neziroglu, Khemlani-Patel, \& Veale, 2008). Eldred, Ward, Dutton and Snowdon (2004: p. 7) define self-esteem as “...more than feeling good about your self. It is also about being aware of your abilities. It is about who you are, being able to acknowledge positive and negative aspects and still feel good about yourself. It's about having a positive sense of identity.”

Everyone has some level of self-esteem, and developing selfesteem is a fundamental human need (Branden, 1994). Eldred, Ward, Dutton and Snowdon (2004: p. 7) suggest that there are many definitions of self-esteem, but the general theme in the literature is that self-esteem is related to the twin aspects of worth and competence (Mruk, 1999). For Branden (1994), selfesteem "is the conviction that one is competent to live and is worthy of living” (see also James, 2002, 2003).

According to Fitts (1972), self-esteem is composed of internal and external dimensions. He suggests three interior sub-dimensions of self-esteem: the Self as Object, which refers to the self-identity; the Self as Doer, which refers to the acting self and the criticizing self; and the Self as Observer and Judge, which reflects the values and expectations that affect an individual's evaluations. The third dimension judges, compares, evaluates and sometimes mediates the first two, identity and behavior. In addition to the internal dimensions, Fitts identified the external dimensions of the self as family self-esteem, self-image morality, social self-esteem, physical self-esteem and personal self-esteem.

Other scholars suggest that self-image is composed of many aspects, such as social equity, the academic self, the emotional self, the moral self, the family self and the physical self (Maiano, Begarie, Morin, \& Ninot, 2009).

Some consider personal self-image an innate virtue that is internally developed. An individual brings this virtue to his/her environment after it has been formulated, and self-image is not affected by environmental experiences (Dweck, 2002). Some researchers refer to self-esteem as a dynamic virtue that is socially constructed, learned by the individual during his/her life and constantly evolving as a result of the experiences of the individual, his/her interaction with "significant others" and contact with the environment (Franken, 1994; Harter, 2003; Trzes- niewski, Robins, Roberts, \& Caspi, 2004).

The literature points to a connection between self-esteem and motivation for learning (Harlen \& Crick, 2003; Maxted, 1999; Orth, Robins, \& Widaman, 2012) and shows a positive correlation between positive self-image and motivation (Dweck, 2002; Harlen \& Crick, 2003). Thus, positive self-esteem helps a person to cope with tasks, whereas negative self-esteem encourages a person to avoid tasks that require effort (Jacoby, 2008; Orth, Robins, \& Widaman, 2012). Research findings indicate a positive relationship between self-esteem and performance; more positive self-esteem is accompanied by more effective personal performance, and vice versa (James, 2002, 2003; Orth, Robins, \& Widaman, 2012). A person with a positive self-image is clear, consistent and realistic and behaves in ways that are positive, healthy and effective (Alexander, 2001; Harlen \& Crick, 2003; James, 2002, 2003; LeMone, 2008). Moreover, the literature reports on the relationship among success, control over one's fate, self-efficacy and self-esteem (Baumeister, 2005; Chen, Gully, \& Eden, 2004; Qazi, 2009).

Some studies suggest that demographic characteristics and personal and environmental factors affect the development of self-esteem (O’Dea \& Caputi, 2001; Rhodes, Roffman, Reddy, \& Fredriksen, 2004) in the following ways: 1) age-young people have a less established self-concept, and their self-confidence develops with age and becomes clearer and more defined (Mullis, Dossey, Foertsch, Jones, \& Gentile, 1992; Erol \& Orth, 2011); 2) gender is a significant factor in self-esteem (McMullin \& Cairney, 2004; Moksnes, Moljord, Espnes, \& Byrne, 2010); 3) income and socio-economic status (Leary \& Baumeister, 2000; McMullin \& Cairney, 2004; O’Dea \& Caputi, 2001; Gilligan, 1995); 4) health status (Benyamini, Leventhal, \& Leventhal, 2004); 5) ethnicity (Bachman, O’Malley, Freedman-Doan, Trzesniewski, \& Donnellan, 2010; Birndorf, Ryan, Auinger, \& Aten, 2005); 6) body image (Fitts \& Adams, 1971; O’Dea \& Caputi, 2001; Polce-Lynch, Myers, Kilmartin, Forssmann-Falck, \& Kliewe, 1998); and 7) culture (Arnett, 2008; Baumeister, 2005; Fitts \& Adams, 1971).

In addition, self-image or self-concept is a significant factor in increasing or decreasing an individual's motivation (Alpay, 2000; Harlen \& Crick, 2003; Black \& Wiliam, 1998). People who have a positive self-concept generally have more motivation and self-awareness of their capabilities and limitations (Franken, 1994). Graduate students are significantly more motivated by internal motivation than are first-year students (Rovai et al., 2007). In contrast, low self-esteem reflects low motivation and low confidence (Azar \& Vasudeva, 2006). Studies have associated low self-esteem and low motivation with social status, income and support (Azar \& Vasudeva, 2006), and lowpaying jobs (Mary \& Good, 2005).

This paper examines the relationship between self-esteem and motivation among two student populations. The first includes regular students in the first year of their academic studies, and the second includes pre-academic preparatory students who struggle to be accepted as regular students.

\section{Hypotheses}

This paper proposes two hypotheses:

1) There is a significant and positive relationship between self-esteem and motivation for learning among pre-academic program students.

2) There are differences in self-esteem and motivation for 
learning in both groups (regular students and students in the pre-academic program).

\section{Methods}

The present study is a quantitative study based on questionnaires.

\section{Sample and Study Population}

The study population consists of two groups: all students in the pre-academic preparatory program (76 students) and regular students in their first year of academic study (99 students). The students in the second group were identified through a systematic random sample in the College. The sample ultimately included 175 students, 76 (43\%) of whom studied in the preacademic program. Of these students, 91\% were female, and 9\% were male. Furthermore, $92 \%$ of the participants were between the ages of 20 and 30 years, $87 \%$ of the sample were Muslim, 9\% were Christians, and the rest were Druze. In terms of marital status, $84 \%$ of the participants were single, and $12 \%$ were married. All of the married students (100\%) had children.

The sample of regular first-year students included 99 students, which was $57 \%$ of the entire first-year student population. In this sample, $96 \%$ were women, $98 \%$ were in the age range of 20 - 30 years, $88 \%$ were Muslims, and the rest were Christians. In this sample, $73 \%$ of the participants were single, and $18 \%$ were married. Of the married students, $50 \%$ had children.

\section{Tools}

Data collection was based on a questionnaire that included three categories of questions:

1) Demographics: Gender, age, religion, marital status, number of children up to age 18 .

2) Self-esteem: The self-image items were adapted from the Tennessee Self-Concept Scale-Second Edition (Fitts \& Warren, 1996). The questionnaire was translated from English to Arabic by an educator with knowledge of both languages. To verify the reliability of the translation, two professional judges compared the Hebrew version and the translated version. In the case of substantive comments, changes were made that were acceptable to both parties. In the case of disputes, a third party contributed. An expert provided notes on the grammar and style of the Arabic version. The questionnaire included 87 items addressing self-image. The overall reliability was calculated by Cronbach's alpha and was .90.
3) Motivation for learning: A factor analysis was conducted that yielded three variables:

a) Achievement Aspects: This variable includes the following items: "I value my academic improvement"; "I can identify consistency in my studies"; "I can identify efforts in my studies and my practical work"; "My current studies are my top priority"; "I am satisfied with my academic performance"; and "I express willingness to continue my studies in the future". The Cronbach's alpha reliability of this category was .84 .

b) Self-realization Aspects: This variable includes the following items: "I believe in my ability to succeed in learning and to be a good teacher"; "I complete all of my required assignments"; "I am interested in being a student”; "I believe in my ability to achieve good grades in my practical work"; and "I am strict with my academic success and practical work”. The Cronbach's alpha reliability coefficient was .85.

c) Proficiency of Content Aspects: This variable includes the following items: "When I study, I organize the learning material by category and topic"; "Even when my study materials are not enjoyable, I am careful to take them seriously"; "I can deal with required tasks and assignments"; "While learning, I notice and perform essential operations, and I try to avoid stress and other negative feelings towards my studies". The Cronbach's alpha reliability coefficient was .79.

A learning motivation index was constructed that contained all of the items. The Cronbach's alpha reliability coefficient was .93.

\section{Procedure}

The questionnaires were distributed in the classroom at the end of the 2010-2011 academic year. The author distributed the questionnaires among the students in the classrooms after receiving permission fro the college. The participants received a brief explanation of the study and the confidentiality of the process. The participants were asked to complete the questionnaires at their leisure and to return them to the researcher.

\section{Findings}

This section will present the means and standard deviations of all of the study measures in relation to the two groups. Then, the findings regarding the research hypotheses will be presented. Table 1 shows the average index scores of the two populations, the pre-preparatory academic students and the regular first-year students.

Table 1.

Average index scores (standard deviations) in the two groups.

\begin{tabular}{ccc}
\hline Variable & Pre-preparatory academic students & Regular first-year students \\
\hline General self-esteem & 3.62 & 3.69 \\
& $(.34)$ & $(.29)$ \\
Motivation for learning & 4.75 & 4.78 \\
& $(.54)$ & $(.68)$ \\
General learning motivation & 4.84 & 4.82 \\
& $(.66)$ & $(.79)$ \\
Motivation-achievement & 5.17 & 5.24 \\
Motivation-self-realization & $(.73)$ & $(.84)$ \\
& 4.76 & 4.75 \\
Motivation-proficiency of content & $(.70)$ & $(.78)$ \\
\end{tabular}




\section{Hypothesis Testing}

This study examines two hypotheses related to the relationship between self-esteem and motivation for learning among Pre-academic track and regular students. The findings of the two research hypotheses are as follows.

First hypothesis: A significant and positive relationship exists between self-esteem and motivation for learning among pre-academic program students. To test the hypothesis, we calculated Pearson's correlation coefficients between the self-image dimension and the dimension of motivation for learning for all of the dimensions. The findings are presented in Table 2.

The table shows that the correlations between self-esteem and aspects of motivation are positive and intermediate; that is, self-image improves all aspects of motivation among the study participants.

Second hypothesis: There are differences in self-esteem and motivation for learning in the two groups (regular students and pre-academic track students). To test the hypothesis, we conducted t-test. The findings are presented in Table $\mathbf{3}$, which shows no significant differences between the two populations.

\section{Discussion}

In the present study, we examine the relationship between self-esteem and motivation for learning. To understand the findings in the context of learning motivation, a comparison was made between students in the pre-academic program and regular first-year students. The findings reveal a significant positive correlation between self-esteem and motivation for learning. This may explain students' decision to integrate into a framework that allows them a "second chance" to improve their achievements to meet the criteria for academic study.

These students are able to join the labor market and make money after completing school, although this program is not considered only preparatory. This choice is based on the students' own expectations rather than the expectations of their families and society. It conflicts with the expected order of events in which students enroll in academic study after completing high school; students who do not do so may be considered "failures”.

The lack of a promising future after graduating from high school decreases students' motivation for learning (Abu Asba, 2007), especially because the preparatory course is not sufficient to ensure success and to improve students' progress. The present study shows that despite the implications of integration into pre-academic preparatory studies, this integration may nevertheless contribute toward students' ultimate goals. Students who lack a good self-image may face personal and social "disappointment”.

The literature indicates a causal relationship between selfesteem and motivation for learning and suggests that low selfesteem is a significant barrier to education (Crowder \& Pupynin, 1995; Maxted, 1999; Mruk, 1999). Orth, Robins, and Widaman (2012) believe that positive self-esteem has a significant impact on an individual's success and life experience (Orth, Robins, \& Widaman, 2012). Moreover, high self-esteem helps an individual to feel valuable and proud and to believe that he or she is "good enough" and capable in terms of intellectual and social skills (Sowislo \& Orth, 2012). Positive self-image may be a factor is success in various fields (Baumeister, 2005). Therefore, students' decision to enter a preparatory program and their persistence in attempting to enter the academy is related to their positive self-image, which helps them to address the challenges before them and motivates them to succeed.

The findings reveal no significant difference between the two groups regarding self-esteem. The findings indicate that the self-esteem of preparatory program is sufficient to enable students to learn the regular preparatory course framework necessary for future opportunities. The differences in the behavior of the two groups can be attributed to their national and ethnic status. Abu Asba (2007) argues that minority groups face many obstacles to obtain achievement similar to the hegemonic majority. He believes that education is important for minority groups in society, particularly in multi-cultural societies. Education is an important tool in promoting minorities and disadvantaged groups.

Table 2.

Pearson's correlation between self-esteem and motivation for learning among students in the pre-academic preparatory program.

\begin{tabular}{cc}
\hline Motivation for learning & General self-esteem \\
\hline Motivation for learning & 3.62 \\
& $(.34)$ \\
General learning motivation & 4.75 \\
& $(.54)$ \\
Motivation-achievement & 4.84 \\
\multirow{2}{*}{ Motivation-self-realization } & $(.66)$ \\
${ }_{* * * *}^{*}<<.001$. & 5.17 \\
\end{tabular}

Table 3.

Difference between the two groups regarding self-esteem dimensions.

\begin{tabular}{|c|c|c|c|}
\hline Variable & Pre-preparatory academic students & Regular first-year students & $\mathrm{T}$ \\
\hline General self-esteem & $\begin{array}{l}3.62 \\
(.34)\end{array}$ & $\begin{array}{l}3.69 \\
(.29)\end{array}$ & NS \\
\hline Motivation for learning & $\begin{array}{l}4.75 \\
(.54)\end{array}$ & $\begin{array}{l}4.78 \\
(.68)\end{array}$ & NS \\
\hline General learning motivation & $\begin{array}{l}4.84 \\
(.66)\end{array}$ & $\begin{array}{l}4.82 \\
(.79)\end{array}$ & NS \\
\hline Motivation-achievement & $\begin{array}{l}5.17 \\
(.73)\end{array}$ & $\begin{array}{l}5.24 \\
(.84)\end{array}$ & NS \\
\hline Motivation—self-realization & $\begin{array}{l}4.76 \\
(.70)\end{array}$ & $\begin{array}{l}4.75 \\
(.78)\end{array}$ & NS \\
\hline Motivation-proficiency of content & $\begin{array}{l}3.62 \\
(.34)\end{array}$ & $\begin{array}{l}3.69 \\
(.29)\end{array}$ & NS \\
\hline
\end{tabular}

NS = Not Significant. 
There is increasing awareness among the Arab minority in Israel about the need for and importance of providing education to the younger generation because education ensures social mobility at both the individual and the collective level (Abu Asba, 2007: p. 51). In other words, mobility among students arises from the fact that education is a means to reduce the gaps in various fields and means of obtaining equality.

This study contributes to our understanding of the nature of the relationship between self-image and motivation for learning. The findings show that students in preparatory studies are motivated to learn and maintain a self-image similar to that of regular students.

In sum, this study suggests that this population is not "lost" and has the self-image and motivation to learn in the same ways. It can be concluded that the barriers that are faced by preparatory school students and that reduce their opportunities to enter regular school courses are not related to their self-esteem or motivation. This study does not address the reasons for the factors that hinder the achievement of these students in high school.

\section{Acknowledgements}

This research was supported by the MOFET Institute and the Department of Teacher Education at the Ministry of Education in Israel.

\section{REFERENCES}

Abu-Asba, Kh. (2007). Arab education in Israel: Dilemmas of a national minority. Jerusalem: Floersheimer Institute for Policy Studies.

Alexander, T. (2001). Defining self-esteem. What is self-esteem and why does itmatter? Self-esteem as an aid to understanding and recovery. Mental healthcare, 4, 332-335.

Alpay, E. (2000). Self-concept and self-esteem. London: The Department of Chemical Engineering and Chemical Technology, Imperial College of Science, Technology, and Medicine.

Ames, C. (1992). Achievement goals and the classroom motivational climate. In D. H. Schunk, \& J. L. Meece (Eds.), Student perceptions in the classroom (pp. 25-57). Hillsdale, NJ: Lawrence Erlbaum.

Ames, R., \& Ames, C. (1990). Motivation and effective teaching. In B. F. Jones, \& L. Idol (Eds.), Dimensions of thinking and cognitive instruction. Hillsdale, N.J: ErIbaum.

Arieli, M. (1997). Evaluation of the contribution of academic Pre higher education system. Jerusalem: National Center for Testing and Evaluation.

Arnett, J. J. (2008). The neglected 95\%: Why American psychology needs to become less American. American Psychologist, 63, 602-614. doi:10.1037/0003-066X.63.7.602

Awad, Y. (2009). Pre-academic establishment Sakhnin college: Rationale, objectives and content. Sakhnin: College of Sakhnin for Teacher Education.

Awad, Y., Zoabi, Kh., \& Khalil, M. (2009). Introducing prior training. Bmekhlala, 22, 238-211.

Azar, A. S., \& Vasudeva, P. (2006). Self-efficacy and self-esteem: A comparative study of employed and unemployed married women in Iran. The German Journal of Psychiatry, 9, 111-117.

Bachman, J. G., O’Malley, P. M., Freedman-Doan, P., Trzesniewski, K. H., \& Donnellan, M. B. (2010). Adolescent self-esteem: Differences by race/ethnicity, gender, and age. Self and Identity, Advance Online Publication.

Baumeister, R. F. (2005). Self-concept, self-esteem, and identity. In V. Derlega, B. Winstead, \& W. Jones (Eds.), Personality: Contemporary theory and research (3rd ed.) (pp. 246-280). San Francisco, CA: Wadsworth.

Benyamini, Y., Leventhal, H., \& Leventhal, E. A. (2004). Self-rated oral health as an independent predictor of self-rated general health, self esteem and life satisfaction. Social Science \& Medicine, 59, 1109-1116. doi:10.1016/j.socscimed.2003.12.021

Birndorf, S., Ryan, S., Auinger, P., \& Aten, M. (2005). High self-esteem among adolescents: Longitudinal trends, sex differences, and protective factors. Journal of Adolescent Health, 37, 194-201. doi:10.1016/j.jadohealth.2004.08.012

Black, P., \& Wilima, D. (1998) Assessment and classroom learning. Assessment in Education, 5, 7-74. doi:10.1080/0969595980050102

Brophy, J. (2004). Motivating students to learn. New Jersey: Lawrence.

Broussard, S. C., \& Garrison, M. E. B. (2004). The relationship between classroom motivation and academic achievement in elementary school-aged children. Family and Consumer Sciences Research Journal, 33, 106-120. doi:10.1177/1077727X04269573

CBS-Central Bureau of Statistics (2008). Statistical Abstract of Israel. Jerusalem: Central Bureau of Statistics.

Chee, T. S., Divaharan, S., Tan, L., \& Mun, C. H. (2011). Self-directed learning with ICT: Theory, practice and assessment. Singapore: Ministry of Education.

Chen, G., Gully, S. M., \& Eden, D. (2004). General self-efficacy and self-esteem: Toward theoretical and empirical distinction between correlated self-evaluations. Journal of Organizational Behavior, 25, 375-395. doi:10.1002/job.251

Crowder, M., \& Pupynin, K. (1995). Understanding Learner Motivation. Nottingham: Department for Education and Employment.

Deci, E. L. (2008). Self-determination theory: A macrotheory of human motivation, development and health. Canadian Psychology, 49, 182185. doi:10.1037/a0012801

Deci, E. L., \& Ryan, R. M. (2008). Facilitating optimal motivation and psychological well-being across life's domains. Canadian Psychology, 49, 14-23. doi:10.1037/0708-5591.49.1.14

Deci, E. L., \& Ryan, R. M. (2012). Self-determination theory. In P. A. M. Van Lange, A. W. Kruglanski, \& E. T. Higgins (Eds.), Handbook of theories of social psychology (pp. 416-437). Thousand Oaks, CA: Sage.

Dweck, C. S. (2002). Messages that motivate: How praise molds students' beliefs, motivation, and performance (In surprising ways). In J. Aronson (Ed.), Improving academic achievement. New York: Academic Press.

Eldred, J., Ward, J., Dutton, Y., \& Snowdon, K. (2004). Catching confidence. URL (last checked 1 October 2012). http://archive.niace.org.uk/funds/ACLF/Catching-Confidence-FinalReport.pdf

Elliot, A. J. (2006). The Hierarchical model of approach avoidance motivation. Motivation and Emotion, 30, 111-116. doi:10.1007/s11031-006-9028-7

Elliot, A. J., \& Thrash, T. M. (2001). Achievement goals and the hierarchical model of achievement motivation. Educational Psychology Review, 12, 139-156.

Endler, A., Rey, G. D., \& Butz, M. V. (2012). Towards motivationbased adaptation of difficulty in e-learning programs. Australasian Journal of Educational Technology, 28, 1119-1135.

Erol, R. Y., \& Orth, U. (2011). Self-esteem development from age 14 to 30 years: A longitudinal study. Journal of Personality and Social Psychology, 101, 607-619. doi:10.1037/a0024299

Fitts, H. W. (1972). The self-concept and behavior: Overview and supplement. Nashville: The Dede Wallace Center.

Fitts, H. W., \& Adams, L. (1971). The self-concept and self-actualization. Dede Wallace Center: Monograph III.

Fitts, W. H., \& Warren, W. N., (1996). Tennessee Self Concept Scale, second edition Manual. Torrance, CA: Western Psychological Services.

Franken, R. (1994). Human motivation (3rd ed.). Pacific Grove, CA: Brooks/Cole Publishing Co.

Furtner, M. R., \& Rauthmann, J. F. (2011). The role of need for achievement in self-leadership: Differential associations with hope for success and fear of failure. African Journal of Business Management, $5,8368-8375$

Gibbons, M. (2002). The self-directed learning handbook: Challenging adolescent students to excel. San Francisco, CA: Jossey-Bass.

Gilligan, C. (1995). In a difference voice: Psychological theory and women's development. Cambridge: University Press.

Guay, F., Chanal, J., Ratelle, C. F., Marsh, H. W., Larose, S., \& Boivin, 
M. (2010). Intrinsic, identified, and controlled types of motivation for school subjects in young elementary school children. British Journal of Educational Psychology, 80, 711-735. doi:10.1348/000709910X499084

Harter, S. (2003). The development of self-representations during childhood and adolescence. In M. R. Leary, \& J. P. Tangney, (Eds.), Handbook of self and identity (pp. 610-642). New York, NY: Guilford Press.

Hyosh, T. (2000). Achievements of graduates Pre-academic at a teachers college. Master's Thesis, Tel Aviv: Tel Aviv University.

Jabareen, Y. (2006). Sustainable urban forms: Their typologies, models, and concepts. Journal of Planning Education and Research, 26, 3852. doi:10.1177/0739456X05285119

Jabareen, Y. (2008). An urban leisure site as an ethno-place of trust for an ethnic minority: The case of the German colony in Haifa. Journal of Architectural and Planning Research, 25, 240-253.

Jabareen, Y. (2009). Ethnic groups and the meaning of urban place: The German colony and Palestinians and Jews in Haifa. Cities, 26, 93-102. doi:10.1016/j.cities.2008.12.002

James, K. (2002). Report and literature review into the role of self-esteem as a barrier to learning and as an outcome. Leicester: DfES, NIAC.

James, K. (2003). How self-esteem affects adult learners-Widening participation and raising self-esteem are intimately linked. Adults Learning, 24-26.

Katz, S. (2004). Enhancing elementary school children performance through reflecting on their self-efficacy. Shaanan College Annual, 9, E27-E36.

Klonis, C., Plant A., \& Devine, G. (2005). Internal and external motivation to respond without sexism. Personality and Social Psychology Bulletin, 31, 1237-1249. doi:10.1177/0146167205275304

Leary, M. R., \& Baumeister, R. F. (2000). The nature and function of self-esteem: Sociometer theory. In M. P. Zanna (Ed.), Advances in Experimental Social Psychology (pp. 1-62). San Diego, CA: Academic Press.

LeMone, P. (2008). Analysis of a human phenomenon: Self-concept. International Journal of Nursing Terminologies and Classifications, 2, 126-130. doi:10.1111/j.1744-618X.1991.tb00347.x

Levine, M. P., \& Smolak, L. (2002). Body image development in adolescence. In T. F. Cash \& T. Pruzinsky (Eds.), Body image: A handbook of theory, research, and clinical practice (pp. 74-82). New York: Guilford Press.

Maïano, C., Bégarie, J., Morin, A., \& Ninot, G. (2009). Assessment of physical self-concept in adolescents with intellectual disability: Content and factor validity of the very short form of the physical selfinventory. Journal of Autism and Developmental Disorders, 39, 775787. doi:10.1007/s10803-008-0686-Z

Mary. D., \& Good, G. (2005). Women and mental of cache. URL (last checked 1 October 2012).

www.un.org/womenwatch/daw/csw/mental

McClelland, D. C. (1961). The achieving society. Princeton, NJ: Van Nostrand.

McClelland, D. C. (1965). Toward a theory of motive acquisition. American Psychologist, 20, 321-333. doi:10.1037/h0022225

McClelland, D. C., Koestner, R., \& Weinberger, J. (1989). How do self-attributed and implicit motives differ? Psychological Review, 96, 690-702. doi:10.1037/0033-295X.96.4.690

McMullin, J. A., \& Cairney, J. (2004). Self-esteem and the intersection of age, class, and gender. Journal of Aging Studies, 18, 75-90. doi:10.1016/j.jaging.2003.09.006

Md Nor, M., \& Saeednia, Y. (2009). Exploring SDL amongst children. International Journal of Behavioral, Cognitive, Educational and Psychological Sciences, 1, 33-38.

Moksnes, U. K., Moljord, I. E. O., Espnes, G. A., \& Byrne, D. G. (2010). The association between stress and emotional states in adolescents: The role of gender and self-esteem. Personality and Individual Differences, 49, 430-435. doi:10.1016/j.paid.2010.04.012

Mruk, C. (1999). Self-esteem research, theory and practice. London: Free Association Books.

Mullis, I. V. S., Dossey, J. A., Foertsch, M. A., Jones, L. R., \& Gentile, C. A. (1991). Trends in academicprogress: Achievement of US students in science, 1969-1970 to 1990; mathematics, 1973 to 1990; reading, 1971 to 1990; writing, 1984 to 1990. Princeton, NJ: Educational Testing Service.

Nakanishi, T. (2002). Critical literature review on motivation. Journal of Language and Linguistics, 1, 278-287.

Neziroglu, F., Khemlani-Patel, S., \& Veale, D. (2008). Social learning theory and cognitive behavioral models of body dysmorphic disorder. Body Image, 5, 28-38. doi:10.1016/j.bodyim.2008.01.002

O'Dea, J. A., \& Caputi, P. (2001) Association between socioeconomic status, weight, age and gender, and the body image and weight control practices of 6- to 19-year-old children and adolescents. Health Education Research, 16, 521-532. doi:10.1093/her/16.5.521

Orth, U., Robins, R. W., \& Widaman, K. F. (2011). Life-span development of self-esteem and its effects on important life outcomes. Journal of Personality and Social Psychology, 102, 1271-1288.

Packer, J. (2004) motivational factors and the experience of learning in educational leisure settings. Ph.D. dissertation, Brisbane: Faculty of Education, Queens-land University of Technology.

Polce-Lynch, M., Myers, B., Kilmartin, C., Forssmann-Falck. R., \& Kliewer, W. (1998). Gender and age patterns in emotional expression, body image, and self-esteem: A qualitative analysis. Sex Roles, 38, 1025-1048. doi:10.1023/A:1018830727244

Qazi, T. (2009). Parenting style, locus of control and self-efficacy: A correlational study. Revista Costarricense de Psicología, 28, 75-84.

Rhodes, J., Roffman, J., Reddy, R., \& Fredriksen, K. (2004). Changes in self-esteem during the middle school years: A latent growth curve study of individual and contextual influences. Journal of School Psychology, 42, 243-261 doi:10.1016/j.jsp.2004.04.001

Robbins, S. \& Seymour, J. (1999). Practicing identities: Power and resistance. In S. Roseneil, \& J. Seymour (Eds.), Practicing identities: Power and resistance (pp. 1-10). London: Macmillan Press.

Robbins, S. B., Lauver, K., Le, H., Davis, D., Langley, R., \& Carlstrom, A. (2004). Do psychosocial and study skill factors predict college outcomes? A meta-analysis. Psychological Bulletin, 130, 261-288. doi:10.1037/0033-2909.130.2.261

Rovai, A. P., Ponton, M. K., Wighting, M. J., \& Baker, J. D. (2007). A comparative analysis of student motivation in traditional classroom and e-learning courses. International Journal on E-Learning, 6, 413432.

Saada, N. (2007). Relationship between self-guidance and self-efficacy for learning teaching in colleges teaching Arab students in Israel. Baka Algarve: Al-Qasemi College of Education.

Salili, F., \& Hoosain, R. (Eds.). (2007). Culture, motivation and learning: A multicultural, perspective. Charlotte: Information Age Publishing.

Schunk, D. H. (1991). Self-efficacy and academic motivation. Educational Psychologist, 26, 207-231.

Schunk, D. H. (2000). Learning theories: An educational perspective (3rd ed.). Upper Saddle River, NJ: Prentice-Hall.

Sowislo, J. F., \& Orth, U. (2012). Does low self-esteem predict depression and anxiety? A metaanalysis of longitudinal studies. Psychological Bulletin, Advance online publication. doi:10.1037/a0028931

Trzesniewski, K. H., Robins, R. W., Roberts, B. W., \& Caspi, A. (2004). Personality and self-esteem development across the life span. In P. T. Costa, \& I. C. Siegler (Eds.), Recent advances in psychology and aging (pp. 163-185). Amsterdam: Elsevier Science.

Valle, A., Cabanach, R. G., Nunez, J. C., Gonzalez-Pienda, J., Rodriguez, S., \& Pineiro, I. (2003). Multiple goals, motivation and academic learning. British Journal of Educational Psychology, 73, 7187. doi:10.1348/000709903762869923

Visblay, A. (2007). Routes designated for the Arab population at the pre-academic. Jerusalem: Research and Information Center.

Williams, K. C., \& Williams, C. C. (2011). Five key ingredients for improving student motivation. Research in Higher Education Journal, 121-123.

Zoabi, Kh., \& Awad, Y. (2012). Exploring teaching training using metaphors among Arab students in Israel. Creative Education, 3, 1-7. doi:10.4236/ce.2012.32034

Zoabi, Kh., \& Savaya, R. (2012). Cultural intervention strategies employed by Arab social workers in Israel: Identification and conceptualization. The British Journal of Social Work, 42, 245-264. doi:10.1093/bjsw/bcr071 